\title{
PLASTIC MOISTURE BARPIERS FOR
}

\section{MIGHWAY SUBGRADE PROTECTION}

$$
\begin{gathered}
\text { APRIL, } 1956 \\
\text { No. } 23
\end{gathered}
$$

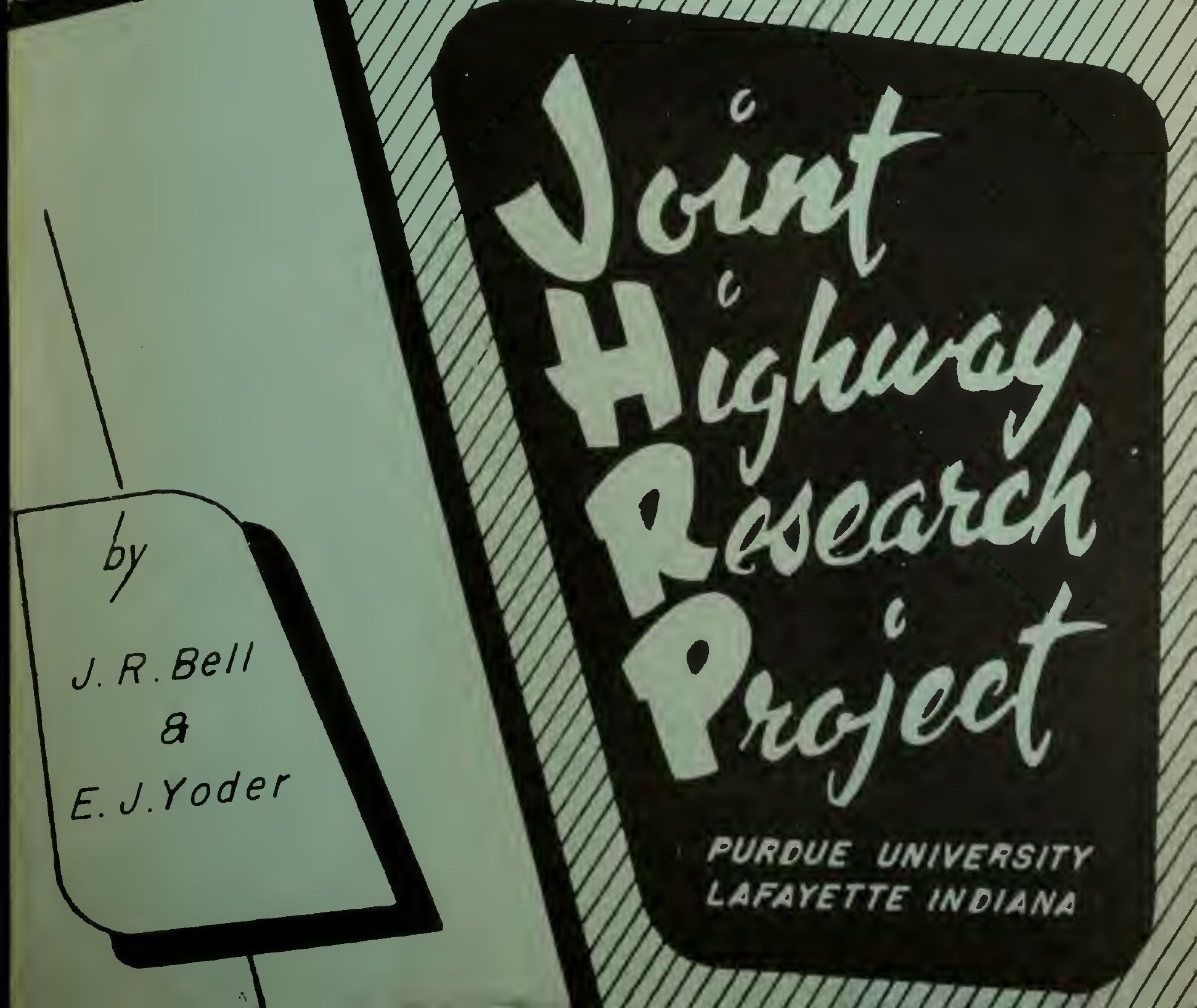




\section{FWSTIC HOISTUPE EAREIERS}

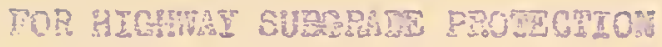

30: X. B. Fiocts, Disoctos

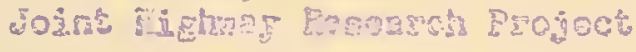

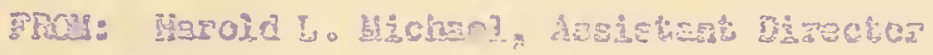

Epin. $19,9.956$

Fis. $160-2-3=28$

$6-133$

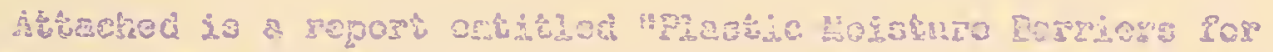

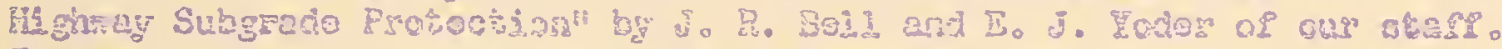

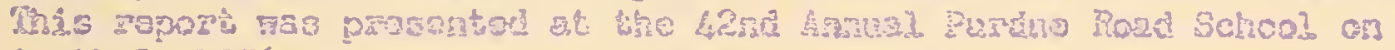
Apri3 2. $59 \%^{\circ}$.

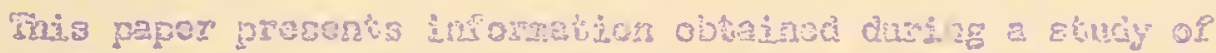
Dlast.

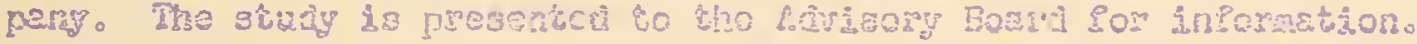

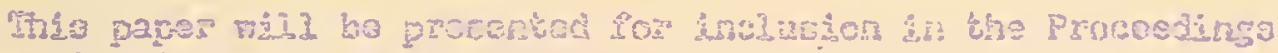

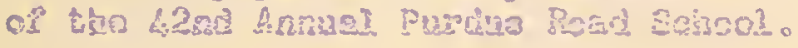

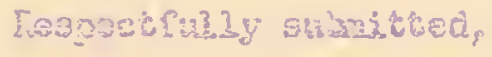

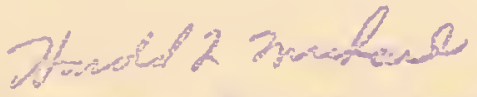

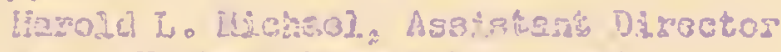

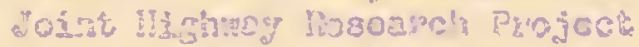

\section{HLi:c3e}

Atbatuent
ec: J. R. COOPOE
‥ E. IOIIE
3. 2. Mำ $110 \mathrm{c}$
2. I. n is
I. I. Maบওy
bicyed Pojiniogion
Co. A. Harticino
3. E. Vogal gos.n" =
G. A. Leczarda
J. L。 "in- $21: 3$
B. B. Levia 
JWASTIC MOISTURE BAPRIERS

FOR KIGHWAY SUBGRADE PROTECTION

Ey

Jo Ro Boll, Research foslatart

and

E。 J. Yodsr, Research ELGanecx

Joint Highway Regeureh Projerst

Puraino Universet.

Sot Roleared for Publ1cationo

Subject to sheugn before

publication by Furdue Univeroltyo

\author{
For presentation u \\ Anisull lleot.tn? \\ Purdzo Koaù Sil 201 \\ Lafayert,e, Indiane \\ Apred $2.5,3.95$
}




\section{INTRODUCTION}

Yost solls, even fine grained solls, can be compacted to have rsala tively high strengths if molsture and density aro propsriy controlled. Howevers under present design corcepts, when those so11s are usad as hlghway subgrades, only a fraction of this uitinate strongth is used as the dasign strength. As a result, large thiskneseca of stronger and more expensive materials are raquired to sprued the load 30 as not to exceed this reduced strength. Thls 18 nesesisary beceuse it 18 known that most subgrade solls will not retain their in.tial strongth after years of service under highmag pavaments. This loss of strength is usually the result of an increaso in water content ard may be accompanied by frost heaving or emelling. If subgrade solls, oubject to theso detrimantal offects of increasing water content, could bs isolstsd froc extorral sources of water, their dasign strengths could be graetIy lncreased effect Ing, In many cases, substantal savings in the total cogt of the highway.

\section{GENERAL}

This paper is a sumary of a resarch projact being conducted at Furdue Univorsity, sponsored by the Batidite Coincany, to javeatigate tho feasibility of using plast1c fllms as molsture basriers to prosect pavement subgrades from changes in water content, The data preseitod aio the results of the laboratory and theorateal iniestigations. The practical. problems of construetion heve nat toen ccapletojy evelusted at this date.

Flgure 1 lliuatratos two pousible appiscalions of plautlc mater barrlers. In the firot caso, tho membrane is slaply a copd.lary cut-off whlch extends across a fill and prevonts nolsture frcm moring uprerd into 
the subgrade. This membrane is represented on the Figure by the dashed 1ine. This installation would be applicablo in areas of noderato ralnfall and high ground water table. It rould eliminate ouch of the problem of frost action as well as protect the subgrade from caplilary wator. The construction of such a wator barries mould bo simplo and inexpensivo. This 18 a promising uso of the plast1c filon that rould be particularly effective whore highways cross net aress on low f1113. The bulk or this paper, however, will be concorned with a molature barrier glving the allarcund protection roquired in arems of greater precipitation where prom tection would also be required on the top and s1dos of the subgrado to prevant novement of water frcm the shouldo:s, distiches, and through ine pavenent. In thls second case, a complete envelope rculd be recossary. The soll would bo completely seried on all sides, and tho onvelope mould extond like a glant bag longitudinaliy under ting pevenent. This io indicated on the Figure by the heary IIno around the envoloped sub-bseo.

Thls second application has the greatest potertial uses of the two. It 18 especially prorialng under flexible pavonents bocause thoy require greater thicknesses of base and sub-baso raterial. than do rigld pavamenta. In this application, the envolepec subgrade soll would replace much of the required granular material anci sems as tha sub-base. Eoth plastic: water barrior installatLons mould groatly reluce the nsed Ior sub drains

Flgure 2 conpares a norral higuway crwes gectios with ore incolm porating a plastic mates barsier enrolope,

If an enveloped soll was uged as the sub-base, tho pajcratit thicknos could bo desiened on the bssis of the ooll's as-cempacted stror:gth and 
Digitized by the Internet Archive in 2011 with funding from

LYRASIS members and Sloan Foundation; Indiana Department of Transportation 
not on the saturated strength as is the comvon practice nom. $\mathrm{Also}_{\mathrm{g}}$ the effects of frost heave or grelling rould bo negligible. In both cases, the total thicisness (T) rould be equal, but for tho envelopsd case, only the thicknegs (S) mould to select material as conpared to the total thickness of select material in the nowal design.

A plastic envelope nould only be justified undor a rigid pavensnt If some factor such as frost action, racher than etrength, control. depth of sub-base, b3cause rigld pevenents do not defend on tholr subsolis for the majority of their strangth and ueualy requiro than basas. Thick bases are nomally used under Portiland Cement conerete parenents only to protect against frost action or smell.1ng。

This paper will be coneerred primarlig vith the problens of tha dyalgn and the economics of a flexible pavenent 1scorpsrating a carplotoly enveloped subgrade material as a sub-basto linis concition is solocted because it has possibly the widest applicat10n.

The points discussed $m i 1$ bo the propertiges of the piatic filns? the strength of enveloped so11;, and the solztive economics of cavelepso versus granular sub-bases. 


\section{THE PLASTIC FIIUS}

Tho types of plastic fllms woro studied in this project: a viny and a polyothylene plastic. These are the gane films that in the last for years have bocome so popular as raincoats, table clothe, food packo ages, and many cther everyday objects.

The plasties havo low pormeabllities, are tough, and aro highly rem slotant to nearly all forms of doterioration. Thes are not sariously affected by acids, alkalies, mold, or oxidatior. Practicaly the only thing occurring in nature that vil affect thsa io uitra-riolet radiation from tho sun, and this 28 no problem when thoy are buried under highwaya.

The plastic would be usod in tho form op manufacturad sheets. Thoy would not bo sprayod onte tho soll. This point is emphegizod boceuso it is often misunderstood that the plest1c woild bo sprayed onto the subgrade as a liquid. Tho filn vould not be spraysd onto tho soll bocause it is more expensive to prccoss the plastic in a liquid form and because thicher flins would be required to insure complete coverage without holes. The flla thicknesses under consideretion are fron 4 to 8 thougandths of an Inch.

The polfethylene fllaro can be obtalngd in widths up to 32 feet. This offers an advantage over the vinyl fsins which are oגg manufactured In Fidthe up to about 20 foet. The poigothwieno is 8180 iose permeable than the vingl. Howsver, tho vinyl ful has ono great Edvantago in that It has the greator realetance to puncture of the two typeso Both flims can bo read1ly spliced by hoat and preosite (heat souling) or by spccial plsstic adhesivas. The cost of these flum l.s epproxtmatoly 10 p per square yard. 


\section{FIIL PERUEABILIII}

Obviarsig in this study ons of the most important properties of the films is pormoability, A study of the mavenent of water through the films hes shown that the term "perneabliltg" as usually used in Civil Englw neering is not applicablo to these plest1ca. The term "porreabijity" 18 generally used in connection with the viscous flon of a Iluid through a porous medium, but sige flims do not have sufilcient pores to pormti vism cous $\mathrm{NCW}$ and rater can only nove througi theq as indivianal nolecules. Therefore, the perneation of the fllm is a form of vapos alffusion (1). This dffusion depends on the vapor preseure gradient across the flim rather than on a hydraullc gradiont as 18 ths case for viecous fler.

The diffusion rates for the mewhanes wise determined at several temperatures and vapor prosgure gradjents and vere folind to bo very $3.0 \%$ for the fllos studied. This will be discussod in greator dotell in lator paregraphi。 
Although the diffusion rates for the fllms aso low, long periods of timo would be involved in a subgrado molsture barrier instillation; there fore, to evaluate the effectiveness of the plastice as water barriers, if is necessary to predict the vapor pressure gradients which might actually be established across the film. This 18 a vory difficult problem becsuse all of the factors 1rvolved are constantly changing with tisme, For sinz plicity, an effort is mede to predict only tire worst posilule condition and from thds to detexmine the meximum rate of water novenent tinsough the membrane.

Since water can permeato the filn ofl.y as a vapor and as a result of a vapor pressure gradient, the problen is one concerned with sol工 vapor pressure relationships. If a closed container is partially filled whin matel, evaporation will take place fron the valer aurfaco and vill continue until the vapor pressure in the atmosphero reaches a value at which evaporation and condensation are equal. Thts coullibricu vapoi pronsuro is equal to the vapor pressure of a free vatar surface and dependa only on temperature. If a molst soll were substituted for the water in the contalner, evaporation would again talse placs until equilibrium betneer. ovaporation and condensation we:o establlshon. Equllibritun would occur In the second case at a lotor vaper preseure becouse the forcos holding the water to the soll rould roduce the vapry pressure of the yoll wates surface below the value for a free water eurfaco. the magntude of this reduetion in vapor pressure depends on the wita. conient of tho onl. 
Therefore, if the relative humidity of the soil is defined as the ratio of the soll water vapor prosaure to the rapor pressure of a free watar surface at the same temperature, it has been found tisat a gives soil 13 ill. have a distlnctive relative hunidity versus wator content curve (2). Figure 3 is a typical soll relutive huridity versus water content. curve. This curve is for a silty clay. The curve for any soll weild have a sinilar shape but rould bo shifted to the left for sands and to the right for clays. The actual values on this curve are not very laportant because they will vary dependirg upon the censity and siructure of the soll. However, the position of the verious sollmater relationshpo on th1s curve is very important. The Atterberg Llolts and the optinun rator content for Standard Proctor Compection Ell fall vary high on the curve. Even the shrinkage limit oceure at a relativa humidity in excess of $90 \%$. For any normal soll condition, the relative humidity insido the envelope would almags be almost es high as the relatito humidity outsids and diffusion nould, therefore, be low.

The maxtoum vapor pressure outside tho snvel.ops wald occur at cemplet, saturation of the soll and Fould correspond to \& relativa humidisy of $100 \%$. The relative humidity of the soll inslds the envelope as compacted would be approximately 99\%. The vapor pressure difference 2 cros 8 the fllo would thon bo only about $1 \%$ of the repar prossure of a firce water aurface. For this vory low proseuro, dffusion nould bo nogligible. If the water were to become redistributiad insids the onve? ope after construction, the gradient could be increased. Ths gratest movement within the envelope rould occur undar freezing conditions with the top 
frozen and the bottom unfrozen. In this case, watsr nould migrate upward to the frozen area, and the water content of the soll adjacent to the lower membrane mould be decreased causing a corresponding decrease in relative humidity. Experinents conducted at the Corps of Enginears Frost Effects Laboratories (3) ohow that the coll water content in this ioner unfrozen area could possibly be decresed to a ralue slightly belon the shrinkage limit. If this condition existed in the envelope, the vapor pressure gradient across the fllm would correspond to a relative humidty difference of about $25 \%$ ( $100 \%$ outa1de, $75 \%$ snvide)。

Figure 4 shows the water transmisalon through the flim plotted against temperature for the condition of $25 \%$ rolative humidity difference acros 8 the flime This Figure shows that, at temperatures which might be enounow tered in the soll (bolow about 55) during freezing of upper layers, diffusion for polyethylene is neglighblo and for vinyl 18 less than 0.2 $1 \mathrm{~b} / \mathrm{ft}{ }^{2} / \mathrm{ys}^{\circ}$. It $1 \mathrm{~s}$ evident that the maximus gradient set forth above could not exist $100 \%$ of the tine since it requires a frecalng condition. During the yearly temporaturo cycle, the gradient would vary fram thio maximum to a mininum of zero. Therefore, the maximum increase in wator content of the enveloped soll nould not axceed abcut $1 \%$ in 10 years for the vingl, and for the polyethylans about $1 \%$ in 100 yoers. Thus, the fllmg are seen to be very offective wator barriers.

The previous discussion polnte out the possibility that same rem distribution of the water within tie enveloped soll might occur, causing a concentration of nater in the uppor part of the envelopo. This Lncrease In water content nould be undesirable, because it rould bring about a loss 
of stabllity in the upper portion where stresses from trafilc lasds would be the greatest. The Preezing gtudies by the Corps of Engirears mentloned bofore Indicate that such morsture concentation will bo small if tha enveloped solls are initially compagtad at less then about sod saturation。 If the envelopod solis are not gabject to freezing, ang pater cortint prectical for compaction ean be used as far as inolisturo migration is concerned. 
STRENGTH OF ENVE OPED SUB-BASE

The next question which arlses $1 \mathrm{~s}$ whether or not the solls to bo envelopod can be compacted et less than $80 \%$ 3aturetion to givo satisfactory atrengtho without resorting to extreordinary compaction mothocs. To answer this question some method of evaluating the supporting capecity of the enveloped solls and of compering tham with nononveloped 80118 is reçuired. The Callfornie Bearing Rat1o (CBR) procedure vas selectod for this purpose (4). The CBR value for onvoloped sub-basos was obtalned by testing tho solls lmmedlately after molding without soaking in water. Th1s value was compared with the standard CBR walues cbtalnod after a 4-day soaking period.

Lost Ilexible pavement design procedures specify a minimum thicknoso of bituminous surface and base course of motoriel with a minlaum CER of 80\%. For this analygis this minimu thicknos of surfaco plus baso courso was selected as 6 Lnches over the top membrano of the envelope. From tho Corps of Englneers CBR highway design curve (Flgure 5) for a 9,000 wheol lording the CBR valuo requiring 6 inches of covor is oqual to $25 \pi$. Thorefore, to ut1120 the envelope nothod of construction to 1ts fullest advantege, It is necessary to compict tho envelopsd soll 30 that 1 will heve en unsoaked CBR of at loast 25\%. If this can be done, the total thickness of surface and base caurso required p111 not oxceed the spec1Iled 6 Inch minlaru,

Two solls, a sllty clay and a plastlc clay, wr tostad and ccmpactIon and CBR curves obtained. A study of the ss data shored that compaction 
of these solls to $95 \%$ of modifled density at modifled optimum mater content resulted in unsoaked CBR values in excess of the required value of $25 \%$ and a dogree of saturation less than $80 \%$. From these results 1t was concluded that many of the more plastic solis can be satisfactorily comm pacted by standard methods to adequatoly servo as highway sub-bases when enveloped。 


\section{ECONOUICS}

Assuming that the enveloped subgrade soll can be compacted to a design CBR of $25 \%$ or greater, the total required thickness of surface and granular material is 6 inches. Without tho snvelope, the total thickross of aggregate required is same finite valug which is controlled by the soaked CBR of the subgrado. The assount of Eranular material replaced by the anveloped subgrade soll nould be this total thickness minus 6 inchos。 For example, assune a soaked CBR of subgrade 3011 equal to 5\%. Then, from the design curve the total patement thickness roculred nould be 16 inches. Th1s thickness minus 6 inches equal.s 10 lnchss and is the thickness of granular subbase naterial repinced. The rolative econondse of the two methods of degiga can be obtained by comparing the cost of 10 inches of suitable granular material in plece pith the coet of constructing a 10 inch thick envelopo.

The cost of the plastic required par mile of 2-lane pavenent is approximately $\$ 3,500$ to $\$ 4,000$. However, it is very difricult to predict eccurately the cost of Incorpcrating a plastic envelope into highway construction becauso some of the construction procodures have not been worked out in deta11. Honevor, some assumptions wore mada and estimates computed. These estimates Ere bellevod to bo at loast of the correct ordor of magnitude.

Flgure 6 is a graphic representation of the cospartion of the cost of normal and enveloped construction. The nlubse on the vertical scalo represent the cost of the granular sub-baso belno raplaced in dollars por 
cublc yard. A range of values is used instead of making the estimate for one speclfic case becaure the prlces vary greatig from location to location, and by this method it can be seen whether or not the possibility of using plastic envelopos is economical for the prices provalent in any specific area. On the horizontal Ecale, 13 shown the thickness in inches of granular materiel that is replaced by the envaloped subgrado. The curver are plots of points which represent savings of approximately $O_{g}$ 5. or 10 thousand dollars per milo of 2-lane pavement, as Indicated on each curve. The sheded area represents conditions where the envelope method of construction would never be economically justifled. To use this curve, it is necessary to know the cost of the granular submbase and the thicknese that could be replaced with protected aubgrade material

For convenfonce, the values of CBR of subgrade and Freazing Index (5) are given on the graph for thelr appropriate saving in granular material. For example, again referring to a CBR equal to $5 \%$, it is remexbered that the savings wore 10 Inches of base; therefore, in the conetruction of Figure 6, CBR of $5 \%$ was placed directls under the thickness of 10 inches, The other values of CBR pero placed in a simflar way. The seme general. schome is followed with the Freezing Indox. (FI) To lliustrata, assuning FI oquals 500 degree dags, a totai pavement thickness of 20 inchos 18 necessary to prevent freezlng of the subgracis. Thls total thlckness of 20 inches minus 6 inches for surface and base cour'so leaves 14 inchse of granular sub-base replaced; note that the freesing lndex of 500 lo located directly under the thickness of $1 / 4$ inches, ifith thls information, it is no longer nacesary to compute the thickness aarod. The CBR or FIn whichover controls the deslgn, can now to $29 e d$ directly, 
To use this chart, simply read up from the soaked CBR of the soll (or freozing index of the location). The horizontal scale of the graph paper givos the thickness of baso saved (actual thickness of enveloped soll roquired). Procoeding up to the cost of baso meterial gives the aquings in cost.

As a further exanplo, assume that tenporaturo recoris for a given Bite Indicate a froezing Index of 400 degree days and a soakred CBR soli of 3\%. From Figure 6 , on the basis of fraezing index the thicliness saver is 12 inches, while for a coaked CBe of $3 \%$ the saving is about 14 inches. For this case the latter is the critical value and the enveloped pavement design mould be 14 inches of snveloped soil plus 6 inches of baee and surface. If the baso cost \$3.00 per cublc foot, the enveloped soll design would be ebout $\$ 6,000$ pers nile choaper than one using no onvelope。

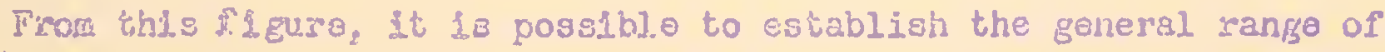
econonic appleability of plastic envolope moisture berriers. It 18 been that $1 \mathrm{i}$ rost action or volura chonge aro not important factors the envolopes are oniy econorical for «so mith jolis which have sonked CBR values leas than about of or $8 \%$ or when sububase materials are vory oxpansive. Homever, when frost acidon io smportant, thie chart shoms thore would bo an appreciable saving whenever the Froozing Indox exceeds Ebout 400 . This is the epproximato valuo for the northers part of Indiana.. Also, thore are large araas of highiy expensivo soils in eoms of tho southern states which requiro pavements at least 18 inches thick to give sufficient confining oressures to prevent excessivo voluno change of the 
subgrade solis. In this caso, subtracting 6 inchos for surface and base leaves a 12 inch saving by the use of plestic watar barriers, and going Lnto the Plgure for 12 inches of granular materlal roplaced gives large 8avings ever et relatirely lom subabio prices.

In the preparation of Figure 6 , 10 aidomance mas macio for savings frem the realuction of sub-drains requirod. The cost of sub-base construc. Hien for the two designs mes the ond item considered. 
CONCLUSIOL

Frone the previcus discussions, it is apparent that thore are areas in the United Strtes which have problems arising from changes in the water contents of highrag subgrade solis and that these probloms could in many cases be econorically solved by tho use of plastic noisture barsiarb. Admithedly there still remain sone unsolved problems but it Is folt that the josults to date justigy continued research on these problens: conequently, at the present timo plans are boing nade to cono thase the straty with the construction of a fullosealo fleld test this surguer。

The results of this field test will bo made avallable at some sutuse date. Finsl jeconmenditions rill be made at that trino. 


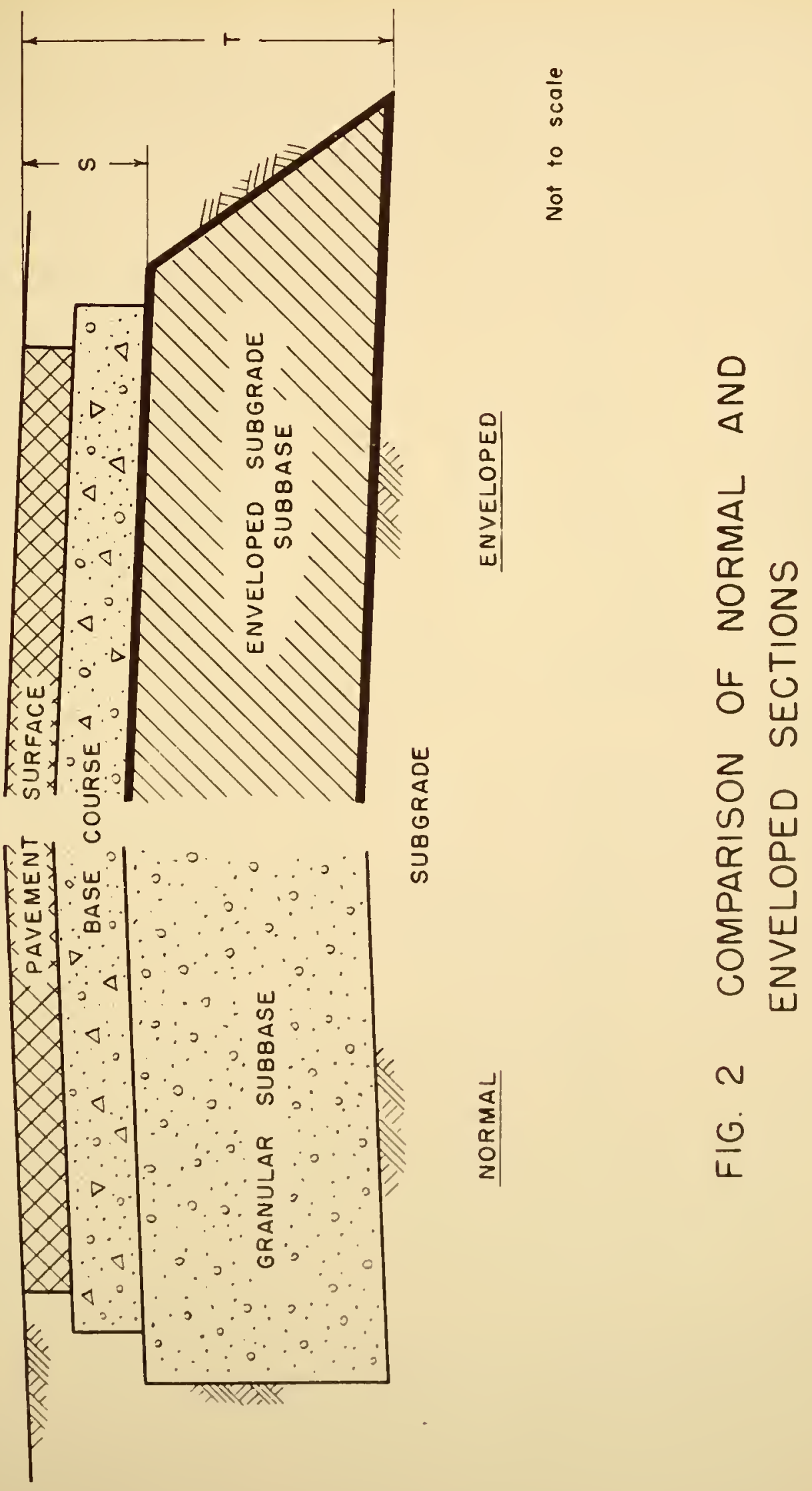




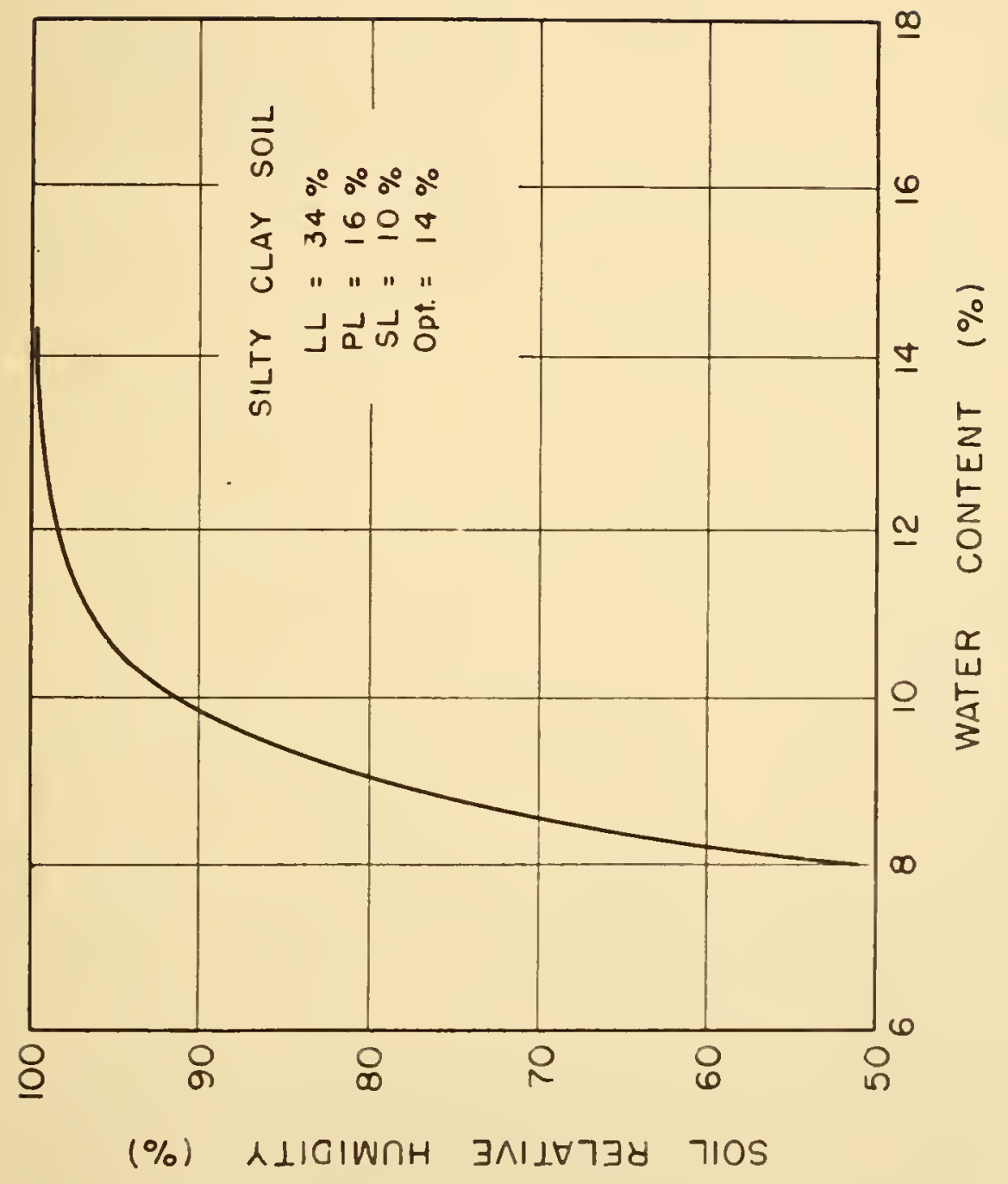

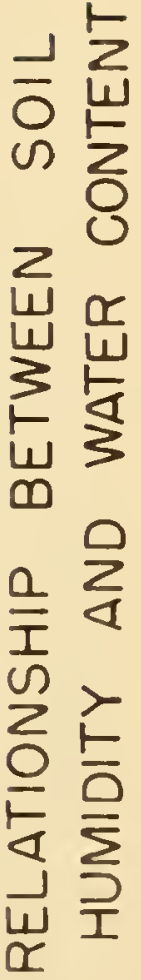

$m \stackrel{w}{\frac{u}{4}}$

는 


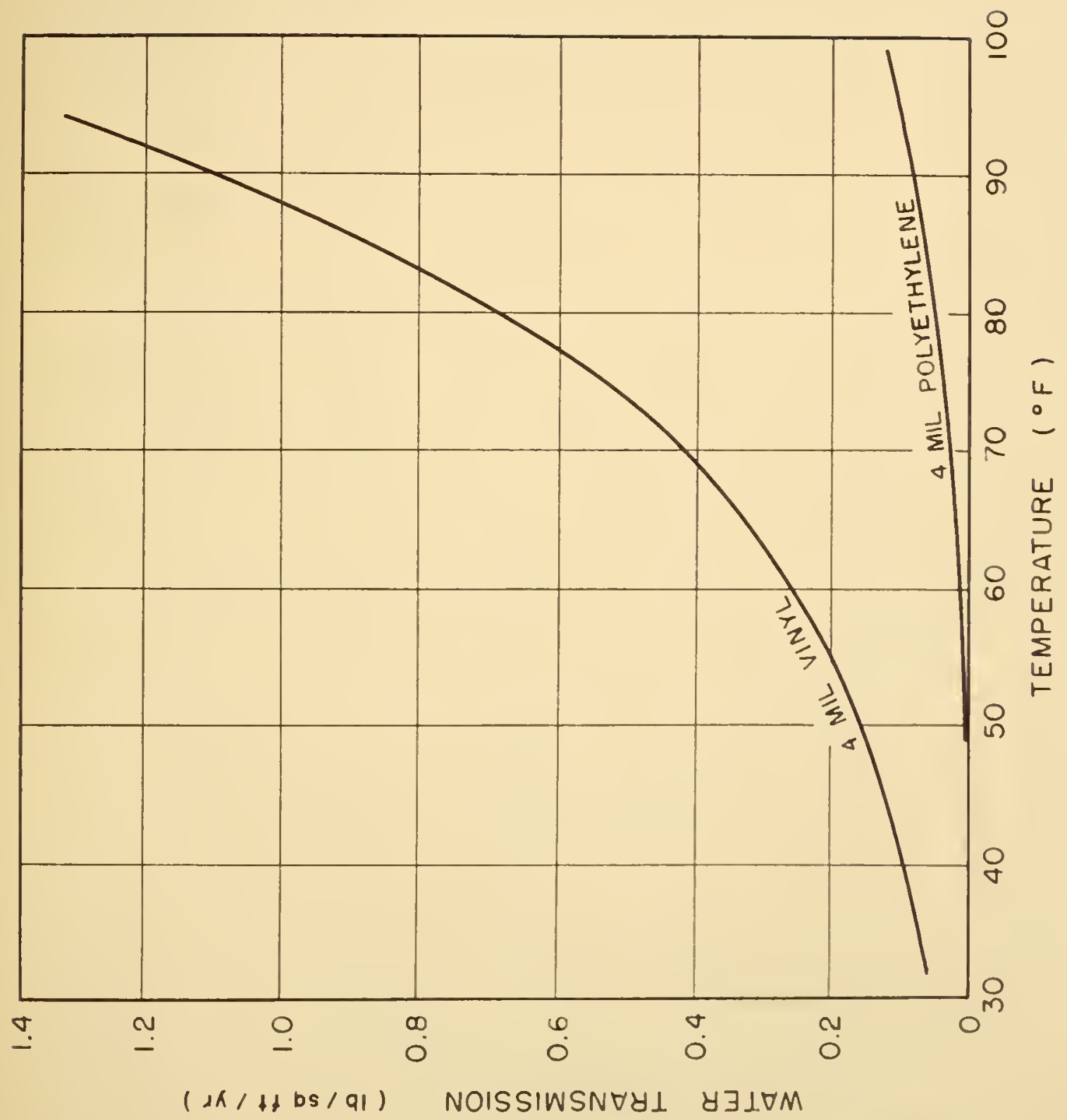

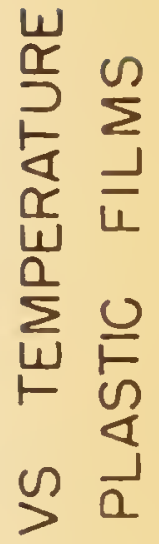

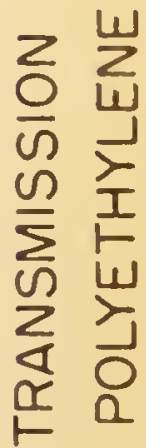

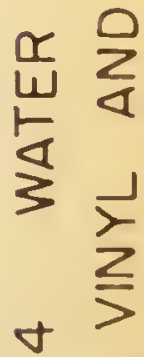

눈 


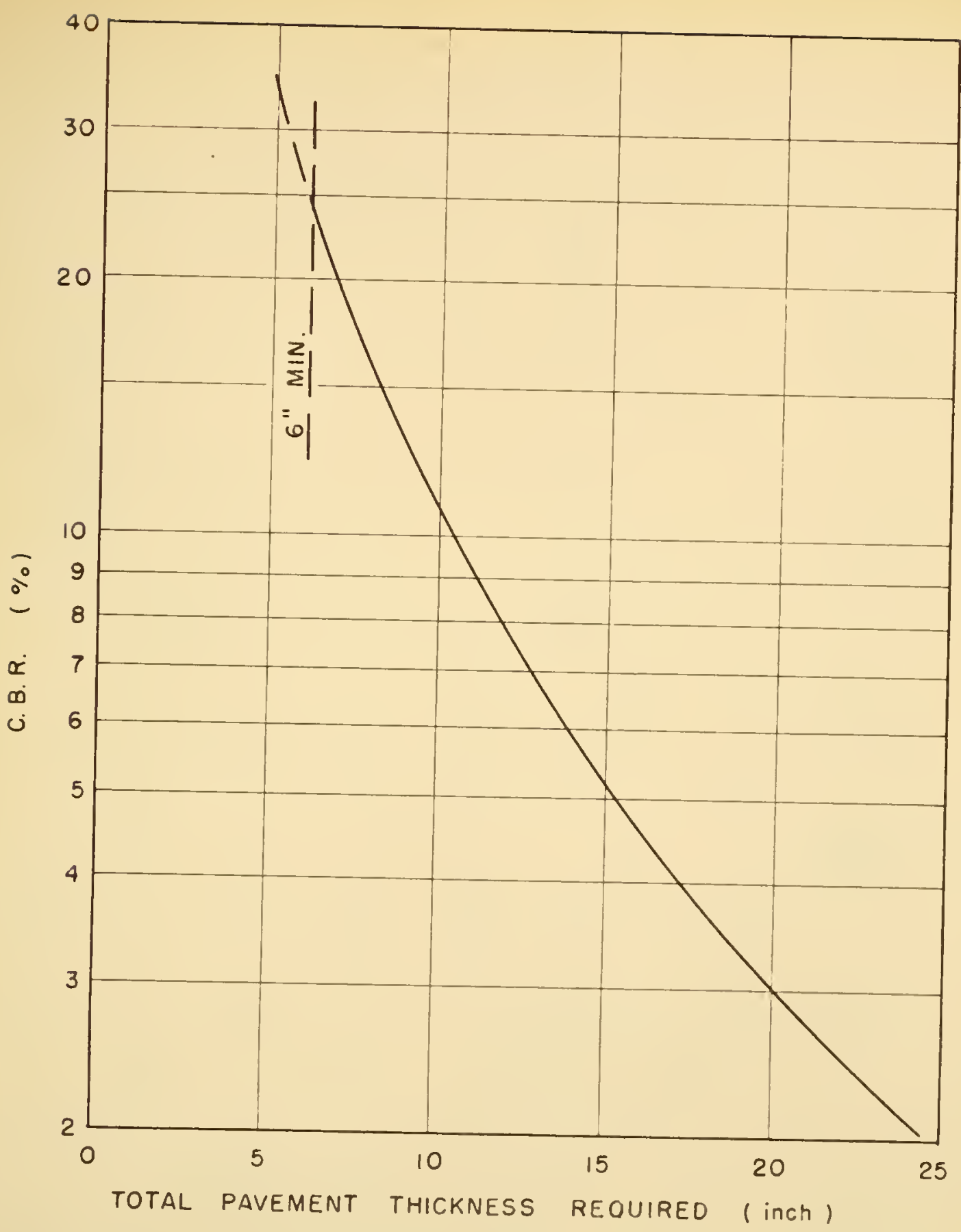

FIG. 5 FLEXIBLE PAVEMENT DESIGN CURVE FOR HIGHWAYS. 9000 LB. WHEEL LOAD 


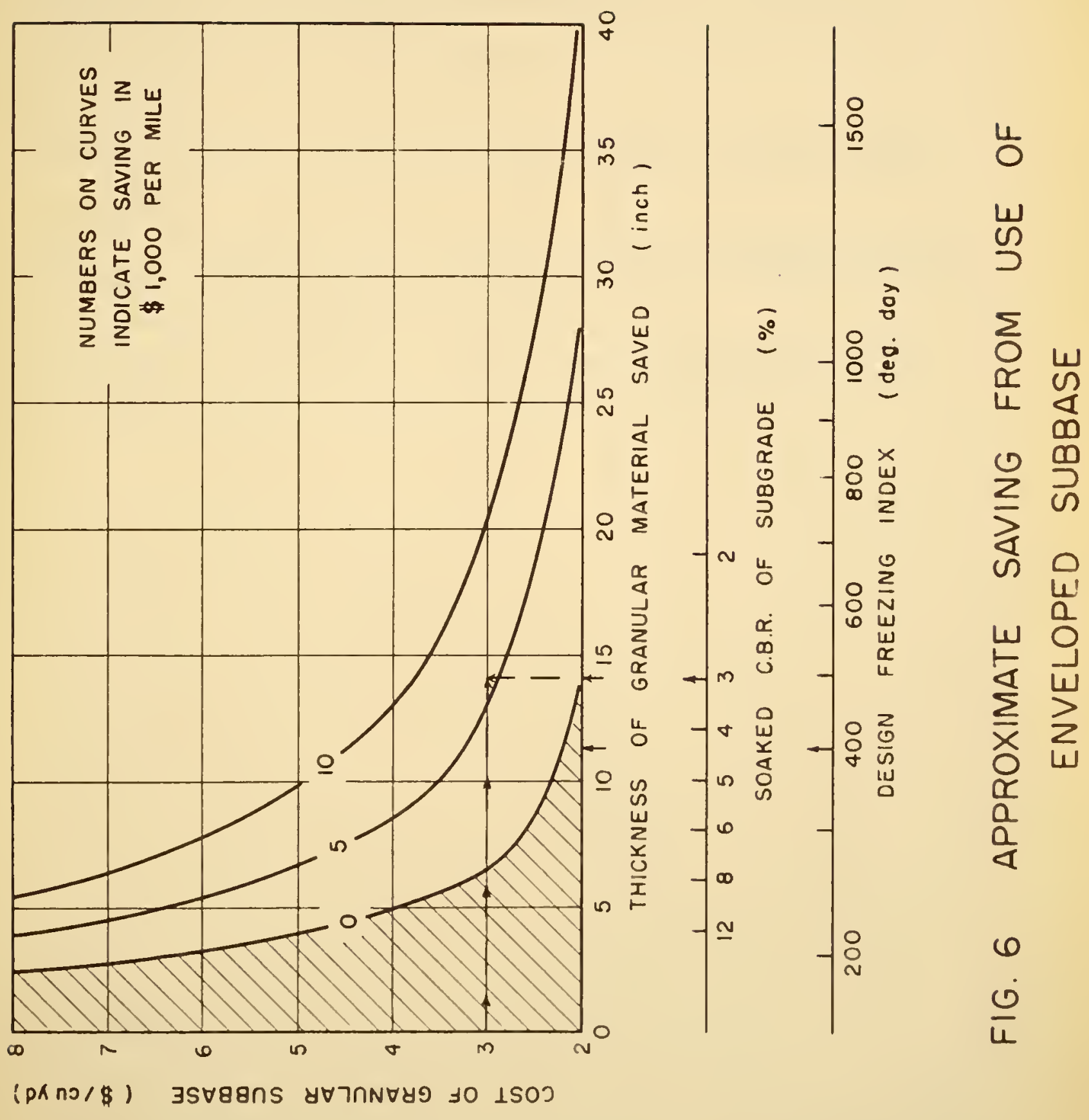


BIBL ICGRAPHY

1. Barrer, $R_{0} \mu_{0}$ "Diffusion in and Through Solids" Cambrago Univariity Press, London, 1941 .

2. "Soll Lechancs for Fosd Inginear" H.H.S.O., London, England, 1952 .

3. "Frost Invosthgrton (Fuscal Year 1952-1953) o Cold Roon Studies Vol. I, Corps of Enginesrs, Frost Effects Iaboratory, Boston, 1953.

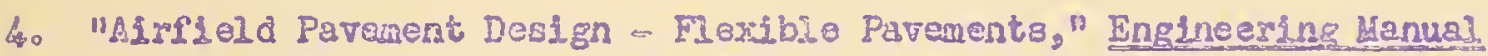
Part XIT, Chap. 2, Corps of Enginerrs, 1951. Including Change I, Har. 1953 and Change? Alpr。1955.

5. "Airfield Prvement Dosign - Frost Conditiono," Engineerdng Lanual Part XII, Chapo is Coros of Enginears, 1953. 

